\title{
ESTUDOS GEOBOTÂNICOS NO VALE DO RIBEIRA COM BASE EM SENSORIAMENTO REMOTO*
}

G.Amaral ${ }^{1}$

Num país tropical úmido como o Brasil, raramente é possível a observação direta de rochas através do sensoriamento remoto. Na maior parte dos casos, o que os sensores registram são as propriedades espectrais da cobertura vegetal, a qual se desenvolve sobre um solo residual ou não.

Geobotânica é um ramo da geoquímica que se ocupa das relações entre a composição química de solos e a cobertura vegetal que neles se desenvolve. Esse relacionamento pode se manifestar de diversas maneiras, desde pequenas alterações na freqüência relativa de espécies, até o total impedimento de desenvolvimento de vegetação. Um aspecto de interesse, no presente caso, é a alteração no comportamento espectral de uma ou mais espécies, por stress geoquímico.

Anomalias na distribuição de elementos maiores ou menores em solos, podem causar perturbações fisiológicas na cobertura vegetal, que podem ser identificadas através de alterações em suas propriedades espectrais no visivel e infravermelho. Assim, espera-se que solos derivados de distintos tipos litológicos possam afetar, de algum modo, a vegetação que sobre eles se desenvolve e que essa alteração se manifeste em produtos de sensoriamento remoto.

De modo a testar essa possibilidade foi apresentado um Projeto Integrado ao CNPq, cujos primeiros resultados são agora relatados. A região do Vale do Ribeira foi selecionada porque apresenta boa diversidade litológica, mata original bastante preservada e disponibilidade de imagens em diferentes épocas do ano.

Um primeiro teste foi desenvolvido com imagens Landsat-MSS de $9 / 11 / 76$, através

\footnotetext{
*Apoio CNPq.

${ }^{1}$ Departamento de Paleontologia e Estratigrafia, Instituto de Geociências, USP/Instituto de Geociências, UNICAMP.
} 
da técnica K-Médias de análise de grupamento não hierarquica e não supervisionada. Segundo esta técnica, $\mathrm{K}$ centros iniciais são gerados, aos quais são agregados os pixels da imagem através de critérios de distância euclideana. Através de procedimento interativo, os centros convergem para os pontos médios de grupos eventualmente distintos, num espaço multidimensional.

Os primeiros resultados obtidos foram bastante satisfatórios, pois os oito grupos individualizados, representados por diferentes cores, distribuem-se de modo muito semelhante ao mapa geológico executado pela CPRM. Dos oito grupos, três correspondem a filitos, dois a granitos e dois a calcários. O oitavo tema tem ocorrência limitada a alguns pixels dentro das classes acima, sem relaçăo aparente com variedades litológicas.

No estágio atual do projeto ainda não fol possivel o teste para um número menor de classes ou aplicação da técnica K-Médias sobre imagens transformadas, de modo a se minimizar os efeitos de iluminação/sombreamento. O projeto também testará esta técnica em imagens LandsatTM e SPOT multiespectrais. Os resultados obtidos até o momento são bastante promissores para aplicações ao mapeamento geológico em regiões densamente florestadas. 